\title{
Analisis Kompetensi Sosial Guru Kelas Vb Sdn 001 Pasar Lubuk Jambi Kab. Kuantan Singingi
}

\section{Vita Julita ${ }^{1 *}$, Febrina Dafit ${ }^{2}$}

1,2 Prodi Pendidikan Guru Sekolah Dasar, Universitas Islam Riau, Pekanbaru, Indonesia

\section{ART ICLE INFO}

\section{Article history:}

Received June 22, 2021

Revised June 30, 2021

Accepted July 14, 2021

Available online July 25, 2021

Kata Kunci:

Kompetensi Sosial , Guru Kelas

\section{Keywords:}

Social Competence, Class

Teacher

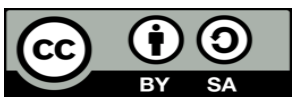

This is an open access article under the CC BY-SA license.

Copyright (C) 2021 by Author. Published by Universitas Pendidikan Ganesha.

\begin{abstract}
A B S T R A K
Kompetensi guru salah satu faktor yang mempengaruhi tercapainnya tujuan pembelajaran dan pendidikan di sekolah, guru harus memiliki kompetensi yang akan digunakan di dalam mengajar di sekolah salah satunya kompetensi sosial guru. Penelitian ini bertujuan untuk mendeskripsikan kompetensi sosial guru kelas VB. Jenis penelitian ini adalah penelitian kualitatif deskriptif. Subjek data pada penelitian ini adalah 1 guru kelas VB, kepala sekolah, 2 rekan guru dan 2 siswa kelas VB. Teknik pengumpulan data yang digunakan adalah wawancara, observasi dan dokumentasi. Teknik analisis data mengunakan model milles and Huberman dengan tahapan, reduksi data, penyajian data, dan penarikan kesimpulan. Hasil Penelitian menunjukkan bahwa kompetensi guru kelas VB sudah kategori sangat baik dan sesuai dengan komponen kompetensi sosial seorang guru yaitu (1) Bersikap inklusif, bertindak objektif, serta tidak diskriminatif karena pertimbangan jenis kelamin, agama, ras, kondisi fisik, latar belakang keluarga dan status sosial ekonomi. (2) Berkomunikasi secara efektif, empatik, dan santun dengan sesama pendidik, tenaga kependidikan, orang tua, dan masyarakat. (3) Beradaptasi di tempat bertugas di seluruh wilayah republik Indonesia yang memiliki keragaman sosial budaya. (4) Bersosial dengan komunitas profesi sendiri dan profesi lain secara lisan maupun tulisan atau bentuk lain. Kesimpulan dari penelitian ini adalah guru kelas VB sudah memiliki kompetensi yang sangat baik dan sesuai dengan indikator kompetensi sosial Permendiknas No 16 Tahun 2007 tentang standar kualifikasi akademik dan kompetensi guru.
\end{abstract}

\begin{abstract}
A B S T R A C T
Teacher competence is one of the factors that influence the achievement of learning and educational goals in schools, teachers must have competencies that will be used in teaching in schools, one of which is teacher social competence. This study aims to describe the social competence of class VB teachers. This type of research is descriptive qualitative research. The data subjects in this study were $1 \mathrm{VB}$ class teacher, the principal, 2 teacher colleagues and 2 VB class students. Data collection techniques used are interviews, observation and documentation. The data analysis technique uses the Milles and Huberman model with stages, data reduction, data presentation, and drawing conclusions. The results showed that the competence of class VB teachers was categorized as very good and in accordance with the components of a teacher's social competence, namely (1) Be inclusive, act objectively, and not discriminate because of considerations of gender, religion, race, physical condition, family background and social status. economy. (2) Communicate effectively, empathically, and politely with fellow educators, education staff, parents, and the community. (3) Adapt to the place of duty throughout the territory of the Republic of Indonesia which has socio-cultural diversity. (4) Socializing with their own professional community and other professions orally or in writing or in other forms. The conclusion of this research is that the teacher of class VB already has excellent competence and is in accordance with the indicators of social competence of the Minister of National Education No. 16 of 2007 concerning standards of academic qualifications and teacher competence.
\end{abstract}

\section{PENDAHULUAN}

Pendidikan adalah salah satu komponen yang penting dalam menghasilkan sebuah sumber daya manusia yang mampu bersaing diabad 21. Pendidikan yang berkualitas akan menghasilkan outcame yang berkualitas pula. Tentunya untuk menghasilkan sebuah pendidikan yang berkualitas ini bukanlah hal yang mudah, harus adanya interaksi yang baik antara komponen-komponen pendidikan. Salah satu komponen yang penting dalam proses pendidikan adalah Guru. Guru adalah individu yang merancang metode komunikasi dan kegiatan yang relevan terhadap kebutuhan, kepedulian dan kemampuan masyarakat di mana mereka berada (Afriadi \& Dahlia, 2020). Guru juga sangat menentukan keberhasilan peserta didik, terutama dalam kaitannya dengan proses belajar mengajar (Nursalim, 2017). Guru sebagai perencana sekaligus sebagai pelaksana pembelajaran serta pemberi balikan untuk memotivasi siswa dalam 
melaksanakan tugas belajar (Ayatullah, 2018). Keberhasilan penyelenggaraan pembelajaran sangat ditentukan oleh kesiapan guru dalam mengelola pembelajaran (Sutardi \& Sugiharsono, 2016). Pentingnya peran guru dalam proses pembelajaran menuntut guru harus menguasai kompetensi yang dibutuhkan untuk menghasilkan sebuah pembelajaran yang berkualitas (Dody, 2016). Kompetensi yang harus dimiliki oleh guru yaitu kompetensi pedagogis, kepribadian, sosial, dan professional (Dahlan et al., 2016; Gani et al., 2018; Jatiningsih et al., 2018). Kompetensi sosial adalah salah satu kompetensi yang wajib dimiliki oleh guru. Kompetensi sosial adalah salah satu kompetensi yang harus dimiliki oleh seorang guru melalui kemampuan guru tersebut dalam berkomunikasi serta bersosialisasi dengan perserta didik, tenaga kependidikan, orang tua/wali murid dan masyarakat luas (Hartini et al., 2021). Selain itu kompetensi sosial juga merupakan kemampuan guru dalam berkomunikasi atau bergaul secara efektif dengan peserta didik, sesama pendidik, bahkan dengan orang tua peserta didik. Seorang guru harus memiliki kompetensi sosial karena jika nantinya ada perbedaan pendapat atau perbedaan nilai dengan masyarakat, seorang guru mampu mengatasi dengan baik tanpa menghambat proses pendidikan (Cahyani \& Andriani, 2014; Muspiroh, 2015). Masalah ini juga serupa dengan penelitian yang menyatakan bahwa seorang guru dituntut untuk memiliki standar komptensi tertentu, yaitu pedagogik, kepribadian, sosial, dan profesional dengan tujuan untuk meningkatkan kualitas pembelajaran (Agung, 2014). Guru yang menunjukkan keterampilan sosial dalam berkomunikasi secara efektif dengan siswa dapat menguasai banyak kata. Untuk memberikan informasi yang lebih baik yang berperan sebagai pembimbing, mendorong untuk aktif dan menjadi guru, pendidik tidak boleh lalai (Rahmawati \& Nartani, 2018). Guru diharapkan menjadi seseorang yang secara langsung dapat memotivasi siswa untuk belajar atau menjadi orang yang selalu diharapkan dalam pertemuan tatap muka di kelas. Komunikasi adalah kunci untuk mempraktikkan kompetensi sosial; Harus ada beberapa prinsip komunikasi untuk memaksimalkan praktik. Prinsipprinsip tersebut adalah; hormat, empati, tutur kata yang jelas (terdengar), apa yang disampaikan dapat dipahami (clarity) dan komunikasi harus dibangun dengan prinsip kesantunan (humble) (Ahmad, 2019). Dari hasil penelitian lain juga menunjukkan bahwa keterampilan sosial guru dapat berpengaruh positif serta signifikan terhadap prestasi belajar siswa (Rafli, 2019). Artinya semakin tampak bahwa kompetensi sosial guru memungkinkan untuk meningkatkan intensitas hubungan sosial guru (Pratiw, 2019). Dari uraian tersebut dapat disimpulkan bahwa kompetensi sosial sangat mempengaruhi kinerja guru sebagai variabel latent endogen untuk mengetahui seberapa besar kontribusi guru yang diberikan kepada peserta didiknya, sehingga dalam berkomunikasi antara guru dan peserta didik tidak ada lagi kesenjangan dalam berkomunikasi maupun bersosialisasi, sehingga terciptanya interaksi yang baik antara seorang guru dan peserta didik.

Masalah kompetensi merupakan salah satu faktor penting di dalam pembinaan guru sebagai suatu jabatan profesi. Menurut Littrell (dalam Uno, 2012:62) kompetensi merupakan suatu kemampuan seseorang dalam bidang tertentu yang diperolehnya melalaui latihan dan praktik ke profesian, yang nantinnya dapat berguna dalam melaksanakan tugasnya sebagai seorang yang memiliki kompetensi sesuai dengan bidang yang ditekuninya. Apalagi untuk seorang guru sebagai pengajar yang dituntut untuk memiliki 4 kompetensi didalam profesinnya sebagai seorang guru salah satunnya yaitu kompetensi sosial. Berdasarkan hasil observasi pada tanggal 22-26 Maret 2021 di SDN 001 Pasar Lubuk Jambi Kab. Kuantan Singingi yang sudah terakreditasi A. Menunjukan bahwa guru di SDN 001 Pasar Lubuk Jambi Kab. Kuantan Singingi, telah menampilkan kompetensi sosial hal ini ditunjukan guru didalam berinteraksi dan berkomunikasi baik dengan sesama rekan guru pada saat berkumpul bersama-sama di ruangan guru dalam berdiskusi membicarakan pembelajaran di sekolah agar dapat berjalan dengan baik setelah beberapa bulan melaksanakan pembelajaran daring dan kembali bertatap muka di sekolah. Namun peneliti masih belum melihat dengan jelas kompetensi sosial guru dalam berkomunikasi dan berinteraksi dengan orang tua/wali murid saat di sekolah. Selain itu peneliti juga melihat bahwa masih kurangnya komunikasi secara afektif guru dengan siswa disekolah dan di dalam proses pembelajaran sehingga hal tersebut membuat daya serap siswa terhadap materi yang disampaikan kurang. Untuk itu diharapkan agar guru dapat memiliki kompetensi sosial yang baik dalam membangun komunikasi dengan baik agar terciptannya interaksi dan hubungan di sekolah berjalan dengan baik (Huda, 2018). Jabaran-jabaran ini memberikan gambaran bagaimana kompetensi social guru berpengaruh terhadap proses pembelajaran. Untuk mengetahui lebih rinci tentang kondisi kompetensi social guru maka penelitian yang bertujuan untuk mengkaji gambaran yang sesungguhnya tentang tingkat kompetensi sosial yang dimiliki guru kelas. Peneliti memilih guru kelas VB untuk di analisis kompetensi sosialnya. Hal tersebut di karenakan guru kelas VB belum lama mengajar di kelas tinggi, sehingga peneliti tertarik untuk meihat bagaimana kompetensi sosial guru kelas VB dengan siswa, orang tua/wali murid, rekan guru di sekolah dan juga masyarakat sekitar sekolah. Untuk itu peneliti ingin melakukan penelitian di SDN 001 Pasar Lubuk Jambi Kab. Kuantan Singingi. Peneliti menetapkan judul penelitian dengan judul "Analisis Kompetensi Sosial Guru Kelas VB Di SDN 001 Pasar Lubuk Jambi Kab. Kuantan Singingi”. 


\section{METODE}

Penelitian ini menggunakan penelitian kualitatif dengan Jenis penelitian deskriptif, penelitian di laksanakan di SDN 001 Pasar lubuk jambi yang beralamat di Pasar Lubuk Jambi, Kab. Kuantan Singingi, dilaksanakan pada bulan Maret-Juli 2021. Sumber data dalam penelitian ini di peroleh dari guru kelas VB, Kepala Sekolah, 2 rekan guru, dan 2 siswa kelas VB. Teknik pengumpulan data di peroleh melalui wawancara, observasi dan dokumentasi. Data yang dikumpulkan berkaiatan dengan Kompetensi sosial menurut Permendiknas No 16 Tahun 2007 tentang standar kualifikasi akademik dan kompetensi guru kompetensi sosial guru yaitu :1) Bersikap inklusif, bertindak objektif, serta tidak diskriminatif karena pertimbangan jenis kelamin, agama, ras, kondisi fisik, latar belakang keluarga, dan status sosial ekonomi.2) Berkomunikasi secara efektif, empatik, dan santun dengan sesama pendidik, tenaga kependidikan, orang tua, dan masyarakat.3) Beradaptasi di tempat bertugas di seluruh wilayah Republik Indonesia yang memiliki keragaman sosial budaya.4) Bersosial dengan komunitas profesi sendiri dan profesi lain secara lisan dan tulisan atau bentuk lain (Yasiko et al., 2021). Keabsahan data menggunakan triangulasi sumber dengan tiga metode yaitu wawancara, observasi dan dokumentasi. Ketiga data tersebut digunakan untuk saling mengecek agar data yang diperoleh dapat terangkum secara menyeluruh. Teknik analisis data mengunakan model milles and Huberman dengan tahapan, reduksi data, penyajian data, dan penarikan kesimpulan

\section{HASIL DAN PEMBAHASAN}

Hasil penelitian tentang kompetensi social yang dilakukan diperoleh beberapa temuan yang menyatakan bahwa kompetensi sosila dilihat dari indicator sikap inklusif, bertindak objektif, serta tidak diskriminatif sudah baik. Temuan pertama, kompetensi social guru dari segi sikap inklusif, bertindak objektif, serta tidak diskriminatif dikatakan sudah baik, hal ini ditunjukkan dengan guru tidak membedabedakan setiap siswa berdasarkan kemampuan akademiknya dan kelainan yang dimiliki oleh siswa apalagi membeda-bedakan siswa dari status sosial kaya atau miskinnya siswa. Guru kelas VB saat proses belajar mengajar memberikan perhatian yang sama terhadap semua siswa baik yang berprestasi dan yang kurang dalam prestasinnya, seperti memberikan penjelasan di kelas jika ada siswa yang tidak paham akan materi yang disampaiakan oleh guru, guru kelas VB akan bersedia untuk menghampiri siswa tersebut untuk menjelaskan hal-hal yang belum siswa pahami begitu juga dengan siswa lainnya di kelas. Guru kelas VB SDN 001 Pasar Lubuk jambi memberikan perlakuan yang adil kepada semua siswa. Seperti saat proses pembelajaran guru akan memberikan nasehat/ motivasi yang baik kesemua siswa. Begitu juga dengan pemberian nilai yang secara objektif dan adil sesuai dengan kemampuan siswa selama belajar dari segi intelegensi, kemampuan kognitif, efektif dan psikomotorik setiap siswa. Serta hasil penelitian yang di lakukan oleh peneliti menunjukkan bahwa guru kelas VB beliau tidak bertindak deskriminatif/ tidak pernah memberikan perlakuan fisik kepada siswannya di sekolah maupun membandingkan siswa berdasarkan gender, kemampuan akademik maupun status ekonomi yang dimiliki oleh siswa. Guru kelas VB mematuhi aturan yang berlaku untuk tidak melakukan tindak kekerasan terhadap siswa di sekolah maupun diluar sekolah yang berujung kekerasan fisik, karna selagi siswa yang bermasalah atau bersangkutan bisa diberikan nasehat guru akan memberikan nasehat kepada siswa tersebut.

Adanya sikap segi sikap inklusif, bertindak objektif, serta tidak diskriminatif akan membuat siswa lebih nyaman serta siswa merasa mendapatkan perlakukan yang sama dalam proses pembelajaran. adanya sikap inklusif, bertindak objektif, serta tidak diskriminatif sangat diperlukan oleh guru. Sikap inklusif adalah sikap guru yang menghargai hak dan perkembangan siswa, sosial dan intelektual, serta pemberian kesempatan untuk mencapai potensinya (Lestari et al., 2017). Guru yang bersikap inklusif dalam mengajar menciptakan suasana belajar yang membuat siswa di dalam kelas merasa bernilai dan memiliki kemampuan untuk melakukan tugas dengan baik. Selian sikap inklusif sikap objektif juga harus dimiliki oleh guru, sikap objektif adalah Objektif berarti dalam memberikan penilaian guru melihat dari fakta dan data di lapangan tanpa ada intervensi dari pihak manapun, serta tanpa ada politik kepentingan didalamnya. Adil sendiri bermakna proposional yang artinya bisa menempatkan sesuatu pada tempatnya. Bertindak objektif berarti bahwasanya guru sebagai figur sentral dalam proses pembelajaran harus senantiasa memperlakukan peserta didik secara proporsional dan tidak akan memilih, memilah, dan berlaku tidak adil terhadap peserta didik (Lestari et al., 2017). Serta sikap tidak diskrininatif adalah sikap tidak membedakan siswa baik dari kemampuan, potensi dan lainya. Ketiga sikap ini jika dikembangkan dengan baik akan menumbuhkan lingkungan belajar yang lebih nyaman, serta terjalinnya interaksi yang baik antara guru dan siswa. Interaksi guru dan siswa dalam pembelajaran merupakan hubungan timbal balik dua arah yaitu guru dan peserta didik dalam kegiatan belajar mengajar yang saling mempengaruhi sehingga terjadi reaksi dari kedua belah pihak. Melalui interaksi antara guru dengan siswa dan interaksi antar sesama siswa (komunikasi dua arah dan multiarah) dalam PBM akan menimbulkan perubahan 
perilaku siswa baik yang berdimensi ranah cipta, ranah rasa maupun ranah karsa (Lisa et al., 2019; Nureva \& Citra, 2018). Berdasarkan jabaran tersebut dapat bahwa adanya sikap segi sikap inklusif, bertindak objektif, serta tidak diskriminatif, akan memberikan dampak yang positif dalam proses pembelajaran dimana siswa akan lebih diberikan ruang yang sama dalam proses pembelajaran.

Temuan kedua. Hasil penelitian menunjukkan bahwa kompetensi social guru dilihat dari segi komunikasi dapat dinyatakan baik hal ini ditunjukkan dari hasil wawancara dimana guru kelas VB sebagai seorang guru beliau berkomunikasi secara efektif dan menciptakan komunikasi yang baik antara siswa, guru, ramah, adil perlakuannya dan gampang bergaul antara guru satu dengan guru lainnya dan saling terbuka satu sama lainnya dalam berdiskusi. Dan menjalin komunikasi yang baik dengan orang tua siswa dalam membimbing dan menginformasikan perkembangan anak di sekolah. Komunikasi dalam proses pembelajaran adalah factor yang sangat penting dalam proses pembelajaran. Komunikasi sangat membantu membangun pemahaman serta mencerminkan pencapaian kematangan dalam hubungan social (Putra \& Jamal, 2020). Kemampuan komunikasi merupakan suatu proses interaksi atau hubungan timbal balik antar individu dengan individu yang lainnya yang saling mengirim pesan dan menerima pesan (Handayani et al., 2021). Keterampilan berkomunikasi memberikan suasana yang mendukung pembelajaran aktif yang mana memiliki kepercayaan diri mengemukakan argumentasinya dan menjadi sarana dalam mengembangkan sikap empati dalam menghargai perbedaan pendapat yang akan mereka temukan dalam lingkungan sehari-hari. Seorang guru harus berusaha mengembangkan komunikasi dengan siswanya secara berkelanjutan sehingga terjalin komunikasi dua arah yang baik (Maslan, 2019). Dalam berkomunikasi dengan siswa, seorang guru harus bisa menggunakan bahasa yang mudah dimengerti, dengan tujuan dapat menjalin komunikasi yang lebih efektif dengan siswa. Selain itu agar terjalinnya komunikasi yang baik, seorang guru juga harus mampu menggunakan bahasa yang baku seperti kata 'aku' diganti dengan kata 'saya', serta menghindari kata-kata atau bahasa yang menyudutkan atau menyalahkan siswa, karena dengan bahasa yang menyudutkan atau menyalahkan siswa, siswa akan merasa kapok untuk menyamapikan pendapatnya, sehingga efek untuk kedepannya akan terjalin komunikasi yang kurang baik antara guru dengan siswa (Masdul, 2018; Muspiroh, 2015; Rombean et al., 2021). jadi komunikasi yang baik antara guru dan siswa akan sangat membatu proses pembelajaran.

Temuan ketiga, pada penelitian yang telah dilakukan, menunjukkan bahwa kompetensi social dari segi kemampuan guru dalam beradaptasi dengan siswa sangat baik, hal ini ditunjukan dari guru kelas VB mampu menyesuaikan dirinnya dengan keragaman budaya di tempatnya bertugas yaitu di SDN 001 Pasar Lubuk Jambi Kab. Kuantan Singingi. Guru kelas VB juga ikut serta untuk mengikuti kegiatankegiatan yang diadakan oleh masyarakat di sekitar sekolah. Guru kelas VB dapat bekerja secara optimal di tempat tugas hal tersebut ditunjukkan dengan guru kelas VB semangat mengajar dan datang tepat waktu serta memiliki tanggung jawab sebagai seorang guru untuk diberikan kepercayaan menjadi guru kelas VB, jika berhalangan hadir untuk mengajar beliau akan menginformasikannya melaui via WhatsApp kepada kepala sekolah atau guru lainnya agar dapat menggantikan beliau untuk mengajar di kelas VB. Begitu juga dengan lingkungan masyarakat di sekitar sekolah terlihat guru kelas VB juga mengikuti kegiatan yang diadakan oleh masyarakat sekitar lingkungan sekolah seperti melakukan gotong royong, bersilaturahmi, dan pengajian. Dari temuan ketiga yang telah dipaparkan di atas, guru sudah mampu menjalankan dengan baik kompetensi sosial sebagai seorang guru, hal tersebut akan berdampak positif bagi guru, terutama di lingkungan mayarakat sekitar. Jika terjalinnya hubungan yang baik anatar guru dengan siswa, rekan kerja guru lainnya, serta masyarakat, maka akan terciptanya harmonisasi dalam pembelajaran yang dilaksanakan, sehingga proses pembelajaran dapat berjalan dengan baik, tanpa adanya pandangan masyarakat yang buruk (Ritonga, 2020; Subianto, 2013; Wahyudi \& Kurniasih, 2020).

Temuan keempat, Kompetensi sosial guru kelas VB dari segi bersosial dengan komunitas profesi sendiri dan profesi lain secara lisan dan tulisan atau bentuk lain. Guru kelas VB dapat bekerja secara optimal di tempat tugas hal tersebut ditunjukkan dengan guru kelas VB semangat mengajar dan datang tepat waktu serta memiliki tanggung jawab sebagai seorang guru untuk diberikan kepercayaan menjadi guru kelas VB jika berhalangan hadir untuk mengajar beliau akan menginformasikannya melaui via WhatsApp kepada kepala sekolah atau guru lainnya agar dapat menggantikan beliau untuk mengajar di kelas VB. Begitu juga dengan lingkungan masyarakat di sekitar sekolah terlihat guru kelas VB juga mengikuti kegiatan yang diadakan oleh masyarakat sekitar lingkungan sekolah seperti melakukan gotong royong, bersilaturahmi, dan pengajian. Dengan sikap guru kelas VB yang kesehariannya selalu mengharagai siswa dan peraturan yang ada di sekolah, maka warga sekolah tentu juga menghargai guru kelas VB, sehingga dengan saling mengharagai satu sama lain, maka akan terciptanya hubungan yang harmonis antara guru dengan siswa, guru dengan rekan guru lainnya, guru dengan kepala sekolah, maupun guru dengan masyarakat di sekitar. Dengan adanya situasi yang nyaman dan tentram, maka akan selalu terciptanya hubungan yang harmonis serta jika kompetensi sosial sudah dilaksanakan dengan baik oleh guru, maka guru tersebut sudah mampu membangun keefektifan dalam dunia pendidikan. Adanya 
sikap harmonisasi yang terjalin maka akan menciptakan serta memperkuat karakter peserta didik, baik itu sikap, perilaku, maupun egonya (Andini, n.d.; Purnamasari \& Amrullah, 2020; Saihu, 2020).

\section{SIMPULAN}

Kompetensi social guru sangat baik hal ini dilihat dari, kompetensi sosial guru dari segi bersikap inklusif, bertindak objektif, serta tidak diskriminatif, kompetensi sosial dari segi berkomunikasi secara efektif, empatik, dan santun dengan sesama pendidik, tenaga kependidikan, orang tua, dan masyarakat, kompetensi sosial guru dari segi beradaptasi di tempat bertugas di seluruh wilayah Republik Indonesia yang memiliki keragaman sosial budaya dan kompetensi sosial guru kelas VB dari segi bersosial dengan komunitas profesi sendiri dan profesi lain secara lisan dan tulisan atau bentuk lain.

\section{DAFTAR PUSTAKA}

Afriadi, B., \& Dahlia, D. (2020). Suvervisi Guru Menggunakan Alat Penilaian Kompetensi Guru (Apkg) Pada Penilaian Komponen Kepribadian dan Sosial Guru di Sdn Jurumudi 5 Kota Tangerang. Jurnal Evaluasi Pendidikan, 11(2), 67-72. https://doi.org/10.21009/10.21009/jep.0124.

Agung, I. (2014). Kajian Pengaruh Kompetensi Kepribadian Dan Sosial Terhadap Kinerja Guru. JIV-Jurnal Ilmiah Visi, 9(2), 83-92. https://doi.org/10.21009/jiv.0902.1.

Ahmad, M. A. (2019). Komunikasi Sebagai Wujud Kompetensi Sosial Guru di Sekolah. Jurnal Komodifikasi, 7, 33-44. http://journal.uin-alauddin.ac.id/index.php/Komodifikasi/article/view/9968/6915.

Andini, novita pri. (n.d.). (Melek IT Vs Mengajar Dengan Hati) Tidak bisa dipungkiri bahwa ledakan internet membawa perubahan besar di semua aspek kehidupan, termasuk dalam dunia ilmu pengetahuan dan teknologi berkembang Kenyataannya dalam kehidupan manusia di era digital ini aka.3(1), 301-307. https://doi.org/10.31002/ijel.v3i1.1725.

Ayatullah. (2018). Peningkatan Keprofesionalan Guru dalam Pembelajaran Pendidikan Agama Islam di MTs Arrohmaniyah NW Senyiur. Palapa, 6(2), 49-74. https://doi.org/10.36088/palapa.v6i2.67.

Cahyani, F. D. \&, \& Andriani, F. (2014). Hubungan Antara Persepsi Siswa Terhadap Kompetensi Pedagogik , Kompetensi Kepribadian, Dan Kompetensi Sosial Guru dengan Motivasi Berprestasi Siswa Akselerasi Di SMA Negeri I Gresik. Jurnal Psikologi Pendidikan Dan Perkembangan, 3(2), 78-88. http://www.journal.unair.ac.id/download-fullpapers-jppp85eb445cb3full.pdf.

Dahlan, Iriawan, H., \& Hamdan. (2016). Pengaruh Kompetensi Manajerial Kepala Sekolah Terhadap Kompetensi Sosial Guru Di Sma Negeri 11 Makassar. Gema Kampus IISIP YAPIS Biak, 11(1), 55-62. https://doi.org/10.52049/gemakampus.v11i1.17.

Dody, S. (2016). Peran Self Awareness dalam Memediasi Pengaruh Supervisi Akademik Pengawas dan Kemampuan Manajerial Kepala Sekolah terhadap Kompetensi Guru. Jurnal Pendidikan Ilmu Sosial, 26(1), 35-43. https://doi.org/10.2317/jpis.v26i1.2063.

Gani, H. M. U., Nur, M., Mallongi, H. S., \& Rusjdin, H. (2018). The Impacts of Competence, Work Motivation, Job Satisfaction and Organizational Commitment on Lecturers' Performance. IRA-International Journal of Management \& Social Sciences (ISSN 2455-2267), 11(1), 17. https://doi.org/10.21013/jmss.v11.n1.p2.

Handayani, S., Masfuah, S., \& Kironoratri, L. (2021). Analisis Kemampuan Komunikasi Siswa dalam Pembelajaran Daring Siswa Sekolah Dasar. Edukatif: Jurnal Ilmu Pendidikan, 3(5), 2240-2246. https://www.edukatif.org/index.php/edukatif/article/view/770.

Hartini, Rahmawati, R., \& Asmin, E. A. (2021). Motivasi, Komitmen Organisasi, Kompetensi dan Dampaknya Terhadap Kinerja Guru. Jurnal Manajemen, 12(1), 52. https://doi.org/10.32832/jmuika.v12i1.3950.

Huda, M. N. (2018). Peran Kompetensi Sosial Guru Dalam Pendidikan. Gastrointestinal Endoscopy, 10(1), 279-288.

http://ejurnal.stail.ac.id/index.php/tadibi/article/view/Peran\%20Kompetensi\%20Sosial\%20Guru\%20d alam\%20pendidikan.

Jatiningsih, O., Maya Mustika Kartika Sari, Habibah, S. M., Setyowati, R. N., Yani, M. T., \& Adi, A. S. (2018). Penguasaan Kompetensi Profesional Guru oleh Mahasiswa Peserta Praktik pengalaman pembelajaran. Jurnal Civics: Media Kajian Kewarganegaraan, 15(1), 170-179. https://doi.org/10.21831/jc.v15i1.17291.

Lestari, J. W., Bahari, Y., \& Budjang, G. (2017). Implementasi Kompetensi Sosial Guru Sosiologi Dalam Berkomunikasi Dengan Peserta Didik Di MAN 1 Pontianak. Jurnal Pendidikan Sosiologi FKIP UNTAN, 5(3), 1-13. https://123dok.com/document/yeo1r87q-implementasi-kompetensi-sosialsosiologi-berkomunikasi-peserta-didik-pontianak.html. 
Lisa, J. L., Ariesta, R., \& Purwadi, A. J. (2019). Analisis Interaksi Guru Dan Siswa Dalam Pembelajaran Bahasa Indonesia Di Kelas Vii Smp Negeri 15 Kota Bengkulu. Jurnal Ilmiah KORPUS, 2(3), 270282. https://doi.org/10.33369/jik.v2i3.6782.

Masdul, muh. rizal. (2018). Komunikasi pembelajaran. Jurnal Ilmu Kependidikan Dan Keislaman, 2(1), 1328. https://doi.org/10.31934/jurnal\%20iqra.v13i2.259.

Maslan. (2019). Hubungan Kompetensi Sosial Guru Kelas Terhadap Penanaman Pendidikan Karakter Siswa Di Sekolah Dasar. JURNAL PAJAR (Pendidikan Dan Pengajaran), 3(6), 1226. https://doi.org/10.33578/pjr.v3i6.7884.

Muspiroh, N. (2015). Peran kompetensi sosial guru dalam menciptakan efektifitas pembelajaran. Jurnal $\begin{array}{lllll}\text { Pendidikan Sosial \& } & \text { Ekonomi, } & \text { 4(2), } & \text { 19. }\end{array}$ https://syekhnurjati.ac.id/jurnal/index.php/edueksos/article/view/655.

Nureva, \& Citra, A. G. (2018). Kontribusi Interaksi Guru Dan Siswa Dalam Pembelajaran Menggunakan Alat Peraga Mini Zoo Mata Pelajaran Ipa Terhadap Hasil Belajar Siswa Mi. Terampil : Jurnal Pendidikan Dan Pembelajaran Dasar, 5(1), 106. https://doi.org/10.24042/terampil.v5i1.2747.

Nursalim. (2017). Profesionalisme Guru SD/ MI. Lentera Pendidikan : Jurnal Ilmu Tarbiyah Dan Keguruan, 20(2), 250-256. https://doi.org/10.24252/lp.2017v20n2i10.

Pratiw, D. (2019). Pengaruh Kompetensi Sosial Guru Pendidikan Agama Islam terhadap Perilaku Peserta Didik SMA Negeri 4 Parepare. http://repository.iainpare.ac.id/id/eprint/683.

Purnamasari, H., \& Amrullah, I. (2020). Harmonisasi Dalam Komunikasi Guru Dan Siswa Di Era Milenial Melalui Bahasa Indonesia Dan Bahasa Tubuh Yang Beretika. Sarasvati, 2(1), 52. https://doi.org/10.30742/sv.v2i1.861.

Putra, B. J., \& Jamal, J. (2020). Profil Keterampilan Komunikasi Interpersonal Siswa. Studi Guru Dan Pembelajaran, 3(3), 399-407. https://e-journal.my.id/jsgp/article/view/410.

Rafli, M. F. (2019). Pengaruh Kompetensi Sosial Guru Terhadap Prestasi Belajar Matematika. September. http://digilib.unimed.ac.id/id/eprint/28077.

Rahmawati, A., \& Nartani, I. (2018). Kompetensi Sosial Guru Dalam Berkomunikasi Pembelajaran Bahasa Indonesia Di SD Negeri Rejowinangun 3 Kotagede Yogyakarta. Jurnal Pendidikan Ke-SD-An, 4(3), 388-392. https://core.ac.uk/download/pdf/230377866.pdf.

Ritonga, N. A. (2020). Peran Kepala Sekolah dalam Menciptakan Iklim Kerja yang kondusif di SD IT Ummi Aida Medan. Continuous Education: Journal of Science and Research, 1(1), 43-55. https: //doi.org/10.51178/ce.v1i1.24.

Rombean, C., Rahmadi, P., \& Appulembang, O. D. (2021). Pentingnya Penyampaian Informasi Yang Tepat Untuk Membangun Komunikasi Efektif Kepada Siswa Kelas Iii Sekolah Dasar [the Importance of Delivering Information Appropriately in Building Effective Communication To Grade 3 of Primary Students]. JOHME: Journal of Holistic Mathematics Education, 5(1), 13. https: //doi.org/10.19166/johme.v5i1.2055.

Saihu, M. (2020). P-issn: 2716-098x, e-issn: 2716-0971. 2(September 2019), 62-79. https://doi.org/10.36671/andragogi.v2i3.116.

Subianto, J. (2013). Peran Keluarga, Sekolah, Dan Masyarakat Dalam Pembentukan Karakter Berkualitas. Edukasia: Jurnal Penelitian Pendidikan Islam, 8(2), 331-354. https://doi.org/10.21043/edukasia.v8i2.757.

Sutardi, S., \& Sugiharsono, S. (2016). Pengaruh Kompetensi Guru, Motivasi Belajar, Dan Lingkungan Keluarga Terhadap Hasil Belajar Mata Pelajaran Ekonomi. Harmoni Sosial: Jurnal Pendidikan IPS, 3(2), 188-198. https://doi.org/10.21831/hsjpi.v3i2.8400.

Wahyudi, D., \& Kurniasih, N. (2020). Dedi Wahyudi. 5, 35-48. https://scholar.google.co.id/citations?user=2fZ0mqsAAAAJ\&hl=id.

Yasiko, D., Guslinda, \& Syahrilfuddin. (2021). Analisis Kompetensi Sosial Guru Sekolah Dasar Gugus IV Kecamatan Sukajadi Kota Pekanbaru. Indonesian Research Journal on Education, 1(3), 114-120. https://journal.universitaspahlawan.ac.id/index.php/irje/article/view/1761/0. 